\title{
Correction to: The statistical shape model as a quality assurance measure in the treatment of complex midface fractures: a case control study
}

Marc Anton Fuessinger ${ }^{1 *}$, Steffen Schwarz ${ }^{1}$, Mathieu Gass ${ }^{1}$, Philipp Poxleitner ${ }^{1}$, Leonard Simon Brandenburg ${ }^{1}$ (D), Stefan Schlager ${ }^{2}$ and Marc Christian Metzger ${ }^{1}$

Correction to: Head Face Med 17, 44 (2021). https://doi.org/10.1186/s13005-021-00296-w

Following the publication of the original article [1], authors spotted error on one of the author names. Leonard Brandenburg should be: (First name) Leonard (Middle name) Simon (Family name) Brandenburg. The correct name is shown above in the author group section.

\section{Author details}

'Department of Oral and Maxillofacial Surgery, Albert-Ludwigs University Freiburg, Hugstetterstr. 55, 79106 Freiburg, Germany. ${ }^{2}$ Department of Physical Anthropology, Albert-Ludwigs University Freiburg, Hebelstr. 29, 79104 Freiburg, Germany.

Published online: 26 January 2022

\section{Reference}

1. Fuessinger MA, Schwarz S, Gass M, Poxleitner P, Brandenburg LS, Schlager S,

et al. The statistical shape model as a quality assurance measure in the treatment of complex midface fractures: a case control study. Head Face Med. 2021;17(1):44. https://doi.org/10.1186/s13005-021-00296-w.

The original article can be found online at https://doi.org/10.1186/s13005021-00296-w.

* Correspondence: marc.anton.fuessinger@uniklinik-freiburg.de

'Department of Oral and Maxillofacial Surgery, Albert-Ludwigs University Freiburg, Hugstetterstr. 55, 79106 Freiburg, Germany

Full list of author information is available at the end of the article

(c) The Author(s). 2022 Open Access This article is licensed under a Creative Commons Attribution 4.0 International License, which permits use, sharing, adaptation, distribution and reproduction in any medium or format, as long as you give appropriate credit to the original author(s) and the source, provide a link to the Creative Commons licence, and indicate if changes were made. The images or other third party material in this article are included in the article's Creative Commons licence, unless indicated otherwise in a credit line to the material. If material is not included in the article's Creative Commons licence and your intended use is not permitted by statutory regulation or exceeds the permitted use, you will need to obtain permission directly from the copyright holder. To view a copy of this licence, visit http://creativecommons.org/licenses/by/4.0/ The Creative Commons Public Domain Dedication waiver (http://creativecommons.org/publicdomain/zero/1.0/) applies to the data made available in this article, unless otherwise stated in a credit line to the data. 